\title{
15 \\ Cultural Memory and the Myth of the Axial Age
}

\author{
JAN ASSMANN
}

The theory of the Axial Age is the creation of philosophers and sociologists, not of historians and philologists on whose research the theory is based. It is the answer to the question for the roots of modernity. When and where did the modern world begin as we know and inhabit it? The historian investigates the past for the sake of the past. The quest for the roots of modernity, however, is not interested in the past as such but only as the beginning of something held to be characteristic of the present. These are two categorically different approaches that must be carefully kept apart, which does not mean, however, that there could and should not be interaction and cooperation between historians and theorists or, to give the distinction a different turn, between specialists and generalists. On the contrary, I think this interaction indispensable if the theory of the Axial Age should be any more than just a scientific myth.

It is the quest for beginnings that gives the Axial theory or narrative a certain mythical quality; myths tend to construct beginnings, which the historian then feels summoned to deconstruct. In the Vorspiel to his Joseph novels, Thomas Mann deals with exactly this tension between the mythical and the historical approach to the past. In the perspective of the historian, the mythical beginnings tend to dissolve and to give way to ever earlier beginnings, and the depth of the "well of the past" proves to be unfathomable. "Tief ist der Brunnen der Vergangenheit. Sollten wir ihn nicht unergründlich nennen?"' This opening sentence describes with inimitable precision the misgivings that historians, especially those who, like myself, specialize in "pre-Axial" civilizations, feel with regard to Karl Jaspers' theory of the Axial Age. To them, Jaspers 
appears as a teller of myths, narrating about beginnings where they see slow developments, continuities, discontinuities, revisions, and recourses.

The myth (and to a large degree also the theory) of the Axial Age is centered on the following principal assumption: there is but One Truth and One Mankind. ${ }^{2}$ At a given point in its moral, spiritual, and intellectual evolution, mankind "broke through" to a much clearer apprehension of this Truth. This happened independently at several places at approximately the same time around $500 \mathrm{BCE}$. In Jaspers' rather tragic view of universal history, these Axial breakthroughs did not really survive their later institutionalizations-at least not undistortedly - when the formative phase of competing small states was followed by the rise of large empires; they remain a goal to be achieved, which gives universal history its normative perspective. If these Axial breakthroughs constitute the roots of modernity, modernity appears as an still unfulfilled project. Mann, in his own ways, adhered to a similar conception. Opposing Oswald Spengler and his theory of eight mutually nontransparent and untranslatable cultural spheres, he propagated the unity of the human spirit ("Die Einheit des Menschengeistes") ${ }^{3}$ across cultural boundaries. In his Joseph novels, he not only showed how such a synthesizing view of different cultural traditions could work with regard to ancient Mesopotamia, Egypt, Israel, Greece, Christianity, but devised also a similar normative concept of modernity as a goal still to be achieved. ${ }^{4}$ As far as the assumption of the unity of humanity is concerned, Mann agreed with the Axial myth, but-as mentioned above-he would never have subscribed to the idea that all this began only in the first millennium BCE. It is important to recognize the political and ideological context of both Mann's and Jaspers' concept of the unity of the human spirit. In the heydays of nationalism, racism, and other theories of human "pseudo-speciation" (E. H. Erikson) $)^{5}$ it was necessary to formulate concepts of human intellectual unity and universal Truthas it is necessary now to remember and to elaborate these concepts in order to overcome the "clash of civilizations" that is now being prophesied by neoSpenglerian theories. In a normative perspective, the myth of the Axial Age has a clear function of orientation. As a reconstruction of the intellectual and social history of the first millennium BCE, however, it is highly problematic.

In a different way, similar misgivings apply to theories of cultural evolution. Theories of evolution reconstruct history in terms of nature, as a largely unconscious, uncontrolled, and in this respect "blind" accumulative progress. 
As far as the history of culture is concerned, however, we are dealing also with processes that involve consciousness, observation, governance, control, reflection, choice, decision, and intervention of various kinds and to various degrees that do not necessarily follow any evolutionary, that is, intrinsic and in this respect "blind" logic. We have to account for losses, intentional breaks, reversions and recourses, rediscoveries, reconstructions. Nobody will deny that there is evolution even in culture. Evolution applies to those areas of culture that lie beyond conscious observation and control, especially processes that run unnoticed and unremembered over a long stretch of time, such as linguistic change or innovations that become an unreflected part of the world in which we are living and that sink below the level of public awareness and discourse to the cultural unconscious. The world we are living in is to a large degree the result of unconscious accumulation. The innovations of former times become the unquestioned and unreflected foundations and presuppositions of later times on which to build in order to find new solutions for new problems. This process, which Pierre Bourdieu called habitualization, may well be described as cultural evolution. It concerns the dark side of collective memory, which lies outside the realm of conscious reflection and communication and which corresponds in many respects to $\mathrm{Mi}$ chel Polanyi's "tacit dimension." ${ }^{6}$ However, the paradigm of evolution loses in applicability if the horizon of unconscious accumulation is transcended and we enter the realm of conscious reflection, debate, and decision, the realm where the "Axial" moves take place. Evolution theory works so well with nature because nature knows of no conscious relationship to the past. Nature neither remembers nor forgets its past. Human beings, however, dispose of a form of memory that allows them to orient themselves in time, in memory back to several millennia and in expectation forward to temporal horizons of varying extension. This human capacity of temporal orientation invests the sheer historical process with meaning in various forms and steers it in various directions. For this reason, evolution theory, if applied to the human world, has to be supplemented by a specifically cultural theory that accounts for the dynamics of the bright, the conscious side of cultural memory.

The Axial Age is unanimously hailed as an evolutionary achievement, a step forward, a "breakthrough" toward the future, toward modernity. It is certainly not a coincidence that its first discovery happened at that other evolutionary moment in the intellectual history of the West that Reinhart 
Koselleck dubbed Sattelzeit (literally "saddle time"), the period between 1750 and 1850 when the idea of "progress" began to move to the center of a new paradigm of historical consciousness. The Iranologist AbrahamHyacinth Anquetil-Duperron (1731-1805) observed as early as 1771 the synchronism between Zoroaster, Confucius, Laotse, Buddha, the prophets in Israel, and the Greek philosophers and spoke of "a great revolution of the human species." ${ }^{7}$ For Koselleck, the Sattelzeit around 1800 marks the beginning of modernity in much the same way as the Axial Age for Jaspers: the boundary between strangeness and familiarity. Both Jaspers' Axial Age and Koselleck's Sattelzeit meant a fundamental restructuring of our orientation in time and our relation to past and future. The paradigm of progress was linked to historicism as a new attitude toward the past, which became important in all its aspects for its own sake, and the Axial "breakthrough" was linked to new forms of relating to the past, of looking backward and cleaving to sanctified, age-old cultural articulations. If it is a breakthrough, this goes in the direction of looking back, of memory, of cultural consciousness and discursive reflection. ${ }^{8}$ In a recent paper, Aleida Assmann criticizes what she calls "modernization theory" for its future-orientedness and its all too exclusive concentration on innovations, changes, beginnings, which necessarily leads to a complete blindness as to the cultural achievements of stabilization and of establishing long-term continuity and diachronic identity. In the framework of modernization theory (to which the theory of the Axial Age obviously belongs), tradition and cultural memory appear as factors of mere retardation, regression, and stagnation. ${ }^{9}$ In the framework of a theory of cultural memory, the Axial Age complex appears in a different light: as a phenomenon of tradition as much as of innovation. Within this methodological framework, the decisive question is not so much what happened in the Axial Age but how have these events been remembered, represented, and reconstructed in cultural traditions.

As far as the breakthrough to monotheism is concerned, this quintessential Axial event is represented in cultural memory as well as in the Axial Age narrative in terms of revolution rather than evolution. Revolution and evolution are in many respects opposites. It is certainly true that revolutions do not occur without preparatory stages, developments, and movements leading in the direction of what is then achieved by a revolutionary transformation or "breakthrough." Nevertheless, the process leading from state A to 
state B via a revolutionary intervention could never be adequately described solely in terms of evolution. As stated above, evolution is "blind," whereas revolution implies observation and decision. An evolutionary process follows exclusively intrinsic vectors without exterior intervention and without decision between opposite options. The best example is perhaps the transition from "primary" to "secondary religions" or "polytheism" to "monotheism." ${ }^{\prime 0}$ Unless we create a specifically cultural (as opposed to biological) meaning of "evolution" that allows for revolution as a means of evolution, this change may never be described in terms of evolution alone. Monotheism is not a more developed state of polytheism. Polytheism does not "lead" to monotheism as its ultimate state of maturity; at most, it leads to a form of inclusive monotheism that views the gods as immanent manifestations of one transcendent supreme deity. Exclusive monotheism, which does not recognize any gods except one, is never the outcome of evolution (as a form of development) but only of revolution (as a form of rejection). ${ }^{11}$

\section{Distance, Disembedment, and Universalism: Features of Axiality}

How could such an interaction between theorists and specialists be realized? First of all, it would be important to come to an agreement concerning the characteristic traits or distinctive features of modernity, whose origins we are looking for in the remote past. What were the decisive innovations that brought about the world which we still inhabit? The first candidate, put forward by Jaspers, is something like general consciousness. In the Axial Age and in the three spheres of China, India, and the West, Jaspers claims, "man becomes conscious of Being as a whole, of himself and his limitations." This kind of "general consciousness" is the hallmark of philosophy, understood as the art of seeing the world and human existence from a distance, a technique of cognitive disembedding from the symbiotic embeddedness of early man in the cycles of nature, political institutions, and social constellations.

The next two features are cognate to this one and hardly separable from it. The first is reflexivity, which Jaspers defines as second-order thinking, thinking about thinking. "Consciousness became once more conscious of itself, thinking became its own object" ("Das Bewußtsein machte noch einmal das Bewußtsein bewußt, das Denken richtete sich auf das Denken"). ${ }^{13}$ 
The second is what Shmuel Eisenstadt calls transcendental visions. Transcendental visions concern concepts with a claim to absolute, unconditioned Truth, with a capital "T." These visions or conceptualizations presuppose new techniques of "standing back and looking beyond" (Benjamin Schwartz), of self-distanciation from the various conditions under which the traditional truths were believed and transmitted, a distance that could be achieved only by very few and only in the first millennium BCE, which the Sinologist Benjamin Schwartz, for this reason, called "the Age of Transcendence." ${ }^{14}$ This is a very convincing characteristic of the intellectual transformations occurring in the first millennium всE in the East and West, but is it also characteristic of modernity? Are we still living in an "age of transcendence," and if so, in what sense? In another context, modernity is defined by the loss of transcendence in the course of the nineteenth century. ${ }^{15}$ More important, however, is the question whether, and in what sense, we can deny the preAxial world any notions of transcendence or "transcendental visions." Obviously, only transcendence in the very strong and emphatic sense of "a cosmological chasm between a transcendental and a mundane sphere" (Hans Joas) can qualify as an exclusively "Axial" concept of transcendence. It is precisely this form of "two worlds theory" that is denied, for example, by Nietzsche's concept of modernity. On the other hand, it applies perfectly well to the pre-Axial world. Even the gods of the polytheistic world are "transcendent" in the sense that they belong to "another" world. Transcendence in the sense of other-worldliness is common to all forms of religion and concepts of the sacred. These gods and spirits are, however, not "extramundane." Their "other-worldliness" does not prevent them from being immanent in nature. For this reason, Eric Voegelin, Talcott Parsons, Robert Bellah, and others have spoken of "cosmological societies" with regard to pre-Axial civilizations, and I try to capture this concept of cosmic immanence of the divine by preferring the term "cosmotheism" to "polytheism." ${ }^{16}$

Voegelin's main criterion for distinguishing between pre-Axial and Axial civilizations (not his terminology) deserves a discussion in this context. It is differentiation, or, in an evolutionary perspective, the transition or turn from "compactness" to "differentiatedness." 17 Axiality, in this perspective, consists primarily in the introduction of new distinctions. My own concept of the "Mosaic distinction" between true and false within the realm of religion and, more generally, between god and world, is in this respect indebted 
to Voegelin's approach. Conceptual "compactness" goes together with analogical thinking. The human world is symbolically articulated on the model of the cosmos, and vice versa (in Voegelin's terms: "microcosmos" and "macranthropos"), a style of thought that I would call "mutual modeling" and which obviously comes very close to Merlin Donald's concept of "mythic culture." Mutual modeling and the ensuing conceptual compactness are based on the "integration of society in nature" (a concept that Voegelin borrows from the Egyptologist Henri Frankfort). Conceptual compactness results not so much from an inability to differentiate, a mere absence of later achievements, but from a will to connect and to integrate, to establish alliances, equations, and identities. Also in this perspective, the Axial turn appears as a process of distanciation and disembedding, leading to or expressed in conceptual differentiation.

Distanciation or disembedding is also a quintessential trait of another feature, which Jaspers calls critique and which may be defined as a new power of negation. "Hitherto unconsciously accepted ideas, customs and conditions," Jaspers writes, "were subjected to examination, questioned and liquidated." 18 This radical questioning of tradition led, according to Jaspers, to monotheism in the eastern, and to the birth of philosophy in the western part of the Eastern Mediterranean. Arnaldo Momigliano put this feature first and spoke with regard to the Axial Age of the "age of criticism."19

It is this power of negation that turns transition into rejection (and evolution into revolution). Unlike Donald and Bellah, who conceive of the various stages of cultural evolution in terms of addition and integration instead of replacement and supersession, ${ }^{20}$ Jaspers constructs the transition from $\mathrm{A}$ to B in terms of A contra B. The success of logos meant the end of mythos, the success of monotheism the end of polytheism (or paganism or "cosmotheism"). The critical, antagonistic, or iconoclastic element in monotheism is unmistakable. Both philosophy (since Parmenides and Plato) and religion (since Moses or what this name stands for) imply a strong concept of absolute Truth, which is in fact a great innovation. This new concept of Truth constitutes the borderline separating what Claude Lévi-Strauss called "la pensée sauvage" from logical and scientific thinking, and "primary," culture-specific religions from "secondary" or world religions. I would in fact subscribe to this theory. The appearance of a new concept of absolute and exclusive truth in the Eastern Mediterranean world is a decisive innova- 
tion. In the paradigm of cultural memory, however, the former stages are neither only "integrated" in the sense of Donald's and Bellah's evolutionary theory, nor are they totally discarded and overcome in the sense of Jaspers' model of intellectual progress. They are excluded, in Aleida Assmann's terminology, from the "canon" and relegated to the "archive" of cultural memory, ${ }^{21}$ from where they might be later recovered, and this rediscovery may then lead to another intellectual revolution such as the Renaissance with its flourishing of cosmotheism, magic, divination, astrology, and other seemingly "pre-Axial" features.

Jaspers describes the direction of this primal turn from mythos to logos and polytheism to monotheism as Vergeistigung (spiritualization), which may be retained as a further feature of axiality. The term comes close to Max Weber's concept of rationalization and disenchantment, and to Sigmund Freud's concept of a progress in Geistigkeit (spirituality or intellectuality). The German word Geist is a notoriously difficult and untranslatable term. It is best understood in the sense of the Greek logos, meaning word, discourse, and reason. Geist has an intimate relationship to language. Vergeistigung means, therefore, something like Versprachlichung, transforming the world into discourse. It is exactly in this sense that Freud interpreted the prohibition of images as a "progress in Geistigkeit."22 The concept of Geistigkeit, which was so important for Freud and Jaspers, gains in significance if seen in the context of the assaults on Geist committed by Nazi Germany. Jaspers' theory of the Axial Age with its characteristic traits of "modernity" is not only a self-portrait or a cultural autobiography but also a normative mirror, confronting modern man with an image of how he should be. As far as the Western part of the Axial hemisphere is concerned, the concept of Geist (ruach, neshamah, pneuma, logos, nous, psyche, animus, spiritus) plays in fact an enormous and ever-increasing role in the cultural texts of the ancient, especially (neo-)Platonic, Jewish, Christian, and, above all, Gnostic worlds.

Another Axial feature, besides general consciousness, second-order thinking, and critique in the name of a new concept of Truth, is the rise of great individuals and the discovery of individuality. The appearance of the "great individuals" such as, from East to West, Confucius, Lao-tse, Meng-tse, Buddha, Zoroaster, the Hebrew prophets and the Greek philosophers, tragedians, and poets is in fact the most striking Axial phenomenon. This is the 
very core of the Axial myth as it was first designed by Anquetil-Duperron and then taken up and elaborated by Jean Pierre Abel-Rémusat, Ernst von Lasaulx, Victor von Strauss, and many others. The great individuals are the few who effectuated the step back and the look beyond, this great achievement of social and ideological disembedding, this display of negational power and radical questioning. Inseparably linked to the discovery of individuality is the stress on interiority, the rise of inner man, homo interior (Augustine), ho endos anthropos (Paul), a kind of inner transcendence-the turn, in David Riesman's terms, from tradition- to inner-directedness. ${ }^{23}$ This turn may also be interpreted as a move of disembedding and distanciation, which appears to be something like a common denominator of all the Axial features enumerated so far.

The most radical form of both social disembedding and interiorization is what Karen Armstrong in her book The Great Transformation (which has been published in German under the title Die Achsenzeit) ${ }^{24}$ calls kenosis, a form of radical renunciation, of disembedding oneself from all social and other "worldly" bonds in the search for the absolute. ${ }^{25} \mathrm{I}$ do not think, however, that we should include kenosis within the Axial features. In its radical form, it seems specific to Indian asceticism, lacking the universality characteristic of typical Axial phenomena. In its more general sense of mere altruism, which Armstrong also includes in her notion of kenosis, it is, on the contrary, far too unspecific and applies also to non-Axial cultures. ${ }^{26}$ This form of renunciation is only a more efficient way of self-embedding into social or communal constellations, not a form of radical disembedding. Disembedding, however, deserves to be retained as a decisive and defining factor of axiality. "The surprising feature of the axial religions," writes Charles Taylor, "is that they initiate a break in all three dimensions of embeddedness: social order, cosmos, human good." ${ }^{27}$

A last feature of axiality has such an importance for Jaspers that he puts it in the very title of his book: history. History, according to him, is the quintessential feature of axiality. History begins with the Axial Age in its three centers-China, India, Israel/Greece - and everything unrelated to one of these centers stays outside history, as a Naturvolk without history. History or historical consciousness functions in Jaspers' theory as a leitfossil of axiality. Since the Axial narrative or theory is in itself a prominent manifesta- 
tion of historical consciousness in the sense of becoming aware and rendering an account of one's own past and origin, it becomes again clear in what sense the Axial narrative is a self-portrait and a cultural autobiography. Historical consciousness, however, is one of the fields where there is most diversity and least convergence among the "Axial" civilizations. ${ }^{28}$

This brief survey has shown that the Axial features have two common denominators. One is a move of distanciation or disembedding, the other the claim for universal validity. To these two general categories, distanciation and universality, has to be added a third one, which, in the context of the Axial narrative, is the most decisive and in my eyes the most problematic one: synchronicity. My impression is that time matters too much in the theoretical debates on the Axial Age. There is the danger of being caught in a vicious circle by including time among the features or conditions of axiality. A phenomenon qualifies as "Axial" if it occurred around $500 \mathrm{BCE}$. It is the temporal argument that gives the Axial process the enigmatic character of an event, a turn, or even a mutation.

Mutation is in fact the way in which Jaspers interpreted the Axial transformation. In the centuries around 500 BCE, "man, as we know him today, came into being," Homo sapiens axialis, so to speak. "The whole of humanity took a forward leap." 29 Voegelin will later speak of a "leap in being" with regard to the Axial event. ${ }^{30}$ The term "axis" refers to a point-the "Axial moment" as Bellah calls it-that divides the stream of time into "before" and "after" in the manner of the birth of Christ. Jaspers' opposition between the Axial and the pre-Axial worlds appears to me in many respects as a secularized version of the Christian opposition of true religion and paganism or historia sacra and historia profana. The biblical (both Jewish and Christian) concept of history implies radical changes, sharp discontinuities, a spiritual "mutation," the emergence of a new man. The Axial Age narrative has the structure of such a mnemohistorical construction that dramatizes a tendency, a development, a process of emergence in form of a revolutionary break, and it personifies it in the figure of a great individual.

The most problematic aspect of such a dramatization of change is the alienation or "estrangement" of the past. ${ }^{31}$ In the same way as Christian (and, for that matter, also Jewish and Islamic) orthodoxy blinded itself for the truths that may be contained in other religions by constructing and rejecting 
them as paganism, idolatry, or "ignorance" (jahiliya, the Muslim concept of paganism), Jaspers seems to be blind to truly Axial motifs in pre-Axial civilizations.

Little consensus has been achieved as to the agents of change. What could possibly bring about such a general transformation or fuel a process of longue durée? Jaspers subscribed to Alfred Weber's theory about the Reitervölker, equestrian tribes or peoples, who by means of their new technology of horse-riding and chariot-driving were able to overrun the ancient world. ${ }^{32}$ Such migrations, invasions, and conquests did in fact happen, but not in the Axial Age. The most decisive wave occurred in the first half of the second millennium вСE, with a second wave around 1200-1100 вСE. The first gave rise to the Hittite Empire, while the second destroyed it, and it also put an end to the Bronze Age in general. It is, however, more than unclear how these events could be related to intellectual and spiritual breakthroughs of the kind Alfred Weber and Jaspers are reclaiming for the Axial Age. If we look for something similar on the political plane taking place around $500 \mathrm{BCE}$, we find the establishment of the Persian Empire in the West, the Maurya kingdoms in India, and the period of the warring kingdoms in China.

The interesting fact about the Persian Empire is that it constituted at its time the most extensive move of globalization in human history. This may have promoted the emergence of universalist ideas. By globalization I understand a process of coalescence of various previously isolated zones into one system of interconnections and interdependencies, where everything, that is, all nations, empires, tribes, and states cohere in some way or other by political, economic, or cultural relations. Universalism, on the other hand, refers to the rise of theories, ideas, or beliefs with a claim to universal validity. By universalism, therefore, I understand an intellectual and spiritual phenomenon; by globalism, a political, economic, and civilizational process (implying material rather than spiritual culture). ${ }^{33}$ The two typical universalisms of Western antiquity are monotheism, both in its inclusive ("all gods are One") and exclusive, biblical form ("no other gods!") on the one hand, and Greek science and philosophy on the other. Since globalization is a central aspect of modernity, we are in fact dealing here with one of its roots.

Imperialism, however, is not the only form of political globalization. In the ancient world, globalization started much earlier, with the emergence of and the contact between the superpowers of the Late Bronze Age in the sec- 
ond half of the second millennium BCE. ${ }^{34}$ The transition in cultural and political outlook, orientation, or mentality to this new stage of incipient globalization may most clearly be observed with respect to ancient Egypt. During the Old and Middle Kingdoms, that is, from 3000 until 1500 вCE, the Egyptians quite simply identified their world with the world in general. Egypt is seen as a cosmos, a sphere of order, surrounded by a zone of chaos, inhabited by nomadic tribes whom it is important to ward off but not to conquer and integrate. The symbolic expression of this attitude is the same as in classical China, a great wall "built to fence off the nomads" (Sinuhe, B17). ${ }^{35}$ Only with the beginning of the New Kingdom around 1500 BCE does the extra-Egyptian world appear as part of God's creation. By then, the Egyptians have learned the lesson that their environment is not only formed by nomadic tribes but by empires much like their own: the Hittite Empire, the empire of Mitanni, the Babylonian and later also the Assyrian empires, the city states of Syria-Palestine, the Minoan and Mycenean states and colonies, and the Nubian state of Kerma that had emerged south of Egypt. Dealing with these states and empires was no longer a matter of exclusion and negation, but of warfare and diplomacy. Egypt had entered the "age of internationalism," a political network that was coextensive with the world as it was known to and conceived of by its members. The change of political and mental orientation was accompanied by a rise of first universalist concepts, above all the idea of a creator who created the whole world in its differentiated variety-including the multiplicity of languages and skin colors-whom the Egyptians identified with the sun. This development culminated in the middle of the thirteenth century $\mathrm{BCE}$, in a veritable religious revolution, the instauration of a purely and exclusively monotheistic religion by King Akhenaten that lasted, however, for only twenty years at most. This Egyptian example provides a paradigm for the connection between globalization and universalism, as well as for the connections between politics and, at least potentially, Axial breakthroughs. We may call this form of globalization "internationalism," which appears as the hallmark of the Late Bronze Age (1500-1100 вCE).

In the form of imperialism, however, globalization seems to be the hallmark of the first millennium BCE. The Assyrians started this politics of unification with the conquests of Tiglat-Pileser III (745-727 вCE), the founder of the Neo-Assyrian Empire, whose successors extended its frontiers as far 
as Egypt. Forming an alliance with the Medes, the Babylonians under Nabopolassar defeated the Assyrians and founded the Neo-Babylonian Empire, which only ninety years later fell victim to the Persian expansion. The Persian Empire lasted about 300 years, until it was conquered by Alexander the Great. The biblical book of Daniel, composed in the year $165 \mathrm{BCE}$, gives an account and an interpretation of this sequence of empires in the two visions recorded in chapters 2 and 7. Daniel is an apocalypsis prophesying the end of history and the advent of the Kingdom of God after the fall of the fourth empire. In its Christian reception, the fourth empire, which originally referred to Alexander's empire (split up under his successors, the Diadochi), was identified with Rome, and because the end of history was not deemed really desirable, the end of Rome was deferred as far as possible in the form of the "Holy Roman Empire." ${ }^{36}$ In this respect, Daniel opens a historical perspective that connects the first millennium BCE with Napoleon, who finally put an end to this construction and aspired to continue this tradition of imperialist globalization by building an ever greater empire. Daniel provided the universalist vision to the globalist project of Hellenistic imperialism. A similar project may have inspired Jaspers after the breakdown of Hitler's global imperialism. It is obvious that the idea of imperialistic globalization emerged in the first millennium вСЕ and remained a major factor in political thought until modernity. In this respect, we may indeed speak of an "Axial Age." But this is not what Jaspers had in mind, and "globalization" is not his theme.

\section{Literacy as an Agent of Change}

As far as the agents of change are concerned, there might indeed exist a relationship between technological and intellectual innovations on the one hand, and political breakdowns and intellectual breakthroughs on the other. ${ }^{37}$ In my contribution to the volume Axial Civilizations and World History, I tried to shed light on the second aspect with regard to Egypt and Israel. ${ }^{38}$ In this contribution, I want to focus on technological and intellectual innovations, dealing, however, not with engineerial technologies of warfare and transportation but with writing as "a technology that restructures thought." 39 I am, therefore, arguing in the field of a semiotics and pragmatics of symbolic forms, which is also treated in the more theoretic contributions to this 
volume by Merlin Donald and Matthias Jung. As early as 1783, the Jewish philosopher Moses Mendelssohn stated that "the grammatological transformations which occurred in different periods of cultural development had an important impact on the revolutions of human cognition in general and changes in religious concepts in particular." ${ }^{40}$ Homo axialis is the man, the symbol-user, who by "mutually reinforcing feedback loops between levels of consciousness and different modes of sign-usage" (Matthias Jung) has been formed by the very tools he invented.

Writing as a cultural technique may be looked at under two different aspects: as a technology of creation and a technology of preservation. Nobody will doubt that, without writing, none of the great texts that we are still reading today could have been preserved in such a manner that they could still exert their normative and formative impact, and that writing, therefore, has to be recognized as a necessary condition of axiality. Few, however, would subscribe to the idea that writing constitutes also a sufficient condition, which would mean that axiality is a causal consequence of writing. I myself would never go so far. There is, however, a third way of conceptualizing the relation between writing and axiality, taking axiality to be not a consequence but an implication of writing, an option opened up by literacy of a certain quality, whose acceptance, exploration, and elaboration, however, depends on historical and cultural circumstances. Until very recently, the invention or reception of writing and the development of literacy have mostly been studied as factors of cultural evolution. In the famous studies of Walter Ong, Jack Goody, Eric Havelock, and others, this has led to a kind of mediadeterminism, taking for inevitable consequences what at best are potentialities, propensities, and implications that may become real only in interaction with contingent political, social, and cultural factors. ${ }^{41}$

Writing is not the same in every context. We have to distinguish between systems and cultures of writing (this distinction will be explained later), and within cultures of writing between several stages of literacy. First of all, however, we have to consider writing as a medium not only of communication but also of memory. Under certain conditions, writing restructures thought not only in the direction of invention but also of retention and may eventually lead to a complete restructuring of what we call "cultural memory." Only writing creates the tension between "canon" and "archive" (Aleida Assmann) that accounts for a cultural dynamism typical of "Axial" cultures. ${ }^{42}$ 
Writing is a technology that makes cultural creations possible that would otherwise never exist, and that preserves cultural creations in memory, making accessible to later recourse what would otherwise be forgotten and have vanished. Writing, in short, is a factor of cultural creativity and cultural memory.

In order to clarify these points, I would like to start with some very general remarks. As human beings we live in a world of symbolic articulation that we ourselves have created. Our world is created through communication. Aristotle's two definitions of man, as zoon logon echon, the animal that has language and reason, and as zoon politikon, the animal that lives in communities, go together: we possess language as a function of our dependency on, and capacity for, bonding, and we use language and other means of symbolic articulation in order to form social bonds and inhabit the world that we create. This space or world of symbolic articulation borders on the inarticulate that we bear in us as the unconscious and that surrounds our world from without.

It is in this space of symbolic articulation and communication that, 5,0006,000 years ago, the space of writing emerged at various places on earth, in very different forms and on different scales, and also with different cultural and social consequences. By writing I understand a special kind of symbols that bestow visibility to the invisible, stability to the volatile, and wide dissemination to the locally confined. Language uses sound-symbols that are invisible, volatile, and locally restricted. Therefore, language is the classical case for the application of writing. In everyday language, by writing we understand language made visible. For other domains of the use of symbols for visibilization, fixation, and dissemination such as music and mathematics, we speak of notation and not of writing. At best, musical notation, at least in German, is often called writing. Notenschrift is a common term in German.

The human space of symbolic articulation and communication was without doubt always occupied not only by acoustic but also by visible symbols. In this sense, humanity has always used writing alongside language. I am thinking of petroglyphs, cave paintings, pottery marks, knotted cords, and other markers in the space of visual communication and of cultural memory, which Donald calls "exograms." 43 There are various means to visibilize the invisible, stabilize the transient, and disseminate the local. It is, however, obvious that by writing or by the various forms of writing that developed at 
various places over 5,000 years ago we understand something different, something that must have changed the space of symbolical articulation more or less radically in proportion to its functions and range. Before going into details here and in order to gain a general idea of this connection between writing and change, I refer to the example of musical notation. There are still many traditions of music that are untouched by musical notation and that correspond to what in the domain of language is called orality. They differ mainly in two points from literate musical traditions: in standardization and evolution or innovation. "Oral" musical traditions tend to be less standardized and less innovative. They are more complex in their use of features that cannot be rendered in musical notation and in spontaneous improvisation, and they are less complex and innovative in the lack of polyphony and in a certain formulaic repetitiveness that is characteristic also of "oral literature." The kind of music, however, that develops in the space of writing shows a breathtaking speed and range of evolution. Eighty years lie between Monteverdi's Poppea and Handel's Alcina, sixty between Alcina and Mozart's Figaro, and another eighty between Cosi fan tutte and Wagner's Walküre. This evolution is a matter both of creativity and of memory. Musical notation enables the composer to create music of unknown complexity and it establishes a memory that excludes unconscious repetition and determines the directions of development by intertextual competition. The Western history of music would not have been possible without the invention of musical notation. This invention brought about a truly Axial turn in that it triggered an evolution of global significance, putting every form of music untouched by it in the position of "folk" or "ethnic" music comparable to the position of oral societies beyond the realm of "history" in Jaspers' sense.

What we may learn from this example of the space of writing is that here a pressure on innovation is prevailing that is alien to the space of orality. There is no more eloquent testimony for this pressure than the Complaints of Khakheperreseneb, an ancient Egyptian author writing in the beginning of the second millennium BCE:

Had I but unknown phrases, strange expressions, new speech that has not yet occurred, free of repetition,

No transmitted proverbs used by the ancestors!

I quench my body of all it contains 
and relieve it from all my words.

For what has been said, is repetition

and nothing is said that has not been said.

One cannot boast with the utterances of the ancestors

for posterity will find out.

$\mathrm{O}$ that I knew what others ignore

and what is not repetition! $!^{44}$

This poignant complaint refers to a problem that only the author has. The public expects from the bard the familiar, but from the author something new. The author has to position himself in a space of intertextual competition. It is through this constant pressure that the space of writing is working on the space of symbolic articulation, modifying but, above all, expanding it. Writing, far from just stabilizing the volatile and visibilizing the invisible, discloses entirely new areas of the inarticulate. Khakheperreseneb's complaint contains many typical Axial motifs such as reflexivity, interiority, individuality: "I quench my body." Tradition made visible through the use of writing assumes an emulatory character. One even thinks of sensing an element of "anxiety of influence" (Harold Bloom) in Khakheperreseneb's complaint. It is, therefore, not enough to state that without writing the great texts would never have been preserved for posterity. Without writing, they would never have been created, because the necessity would not have been felt to go beyond everything already existing in a written tradition. The bard embodies and performs a tradition, an author changes it by adding to it. This is what the Latin word auctor (from augere, to increase, grow, multiply) means.

These effects, however, did not immediately occur with the invention of writing, nor must we think of these changes in terms of evolution, that is, logical consequence and strict determinism. First of all, we have to distinguish, as has already been suggested, between systems and cultures of writing. Writing systems concern differences such as ideographic, logographic, syllabic, alphabetic scripts, and so on; writing cultures concern functions of writing and forms of its social embedding. All the major scripts that are currently in use stem from two sources: the Chinese script and the scripts of the ancient Near East, that is, Egyptian hieroglyphs and Sumerian cuneiform. Already this fact gives us an idea of the interconnectedness of cultural phe- 
nomena. India is a latecomer in this context. Its script (Devanagari) is probably a derivative of the Near Eastern alphabets. The invention of writing is indeed an event of Axial range, dividing the world into literate and oral societies. But it was not the invention as such that led to Axial transformations. This was the first step, and I will try to show that it was only the second and above all the third step in the process of literacy that changed the world.

The first step, the invention of writing, led to what I propose to call "sectorial literacy." ${ }^{45}$ In this stage, writing is used exclusively in those sectors of cultural activity for whose needs it had been invented. In the case of Mesopotamia, this is economy and administration. In Egypt, too, economy or bookkeeping is the central function besides which, however, writing is also used for political representation, funerary monuments, and cultic recitation. In China, writing seems to have originated in the context of divination. In Minoan and Mycenean Greece, writing (Linear A and B) never transcended the realm of economy (bookkeeping) and vanished with the end of the economic system (the palace-culture) that needed it. In Egypt, Mesopotamia, and China, however, the space of writing soon expanded into other fields of cultural practice.

The turn from "sectorial" to "cultural" literacy occurs when writing penetrates into the central core of culture that we (Aleida Assmann and myself) call "cultural memory." This is a question not of a system but of a culture of writing. What matters here is not whether we are dealing with an alphabetic (consonantic or vocalized) alphabet or with a syllabic, logographic, or ideographic script, and the theories especially of the Toronto School (Harold Innis, Marshall McLuhan, Eric Havelock, and recently Friedrich Kittler), which put too much stress on the Greek invention of the vocalized alphabet, are in my opinion mistaken on this point. What matters is whether or not writing is used for the composition, transmission, and circulation of "cultural texts." This is the second step toward axiality. It occurred in Mesopotamia toward the end of the third millennium всE, when the sagas of the Gilgamesh cycle were first collected into a continuous epic, and in Egypt at the beginning of the second millennium $\mathrm{BCE}$, where the first truly literary texts were composed.

"Cultural memory" is that form of collective memory that enables a society to transmit its central patterns of orientation in time, space, and divine 
and human worlds to future generations and by doing so to continue its identity over the sequence of generations. ${ }^{46}$ Cultural memory provides a kind of connective structure in both the social and temporal dimensions. It provides that kind of knowledge that enables an individual to belong, and since human beings need to belong, they serve their drive to belong by acquiring the relevant knowledge, which in German is called Bildung, in Greek paideia, in Hebrew musar, and in Egyptian sebayt. We associate with these concepts institutions of reading and writing, bookcases, libraries, schools, universities, and we find it hard to imagine a kind of cultural memory that is not based on writing and literacy.

The contrary, however, is the case. Orality and ritual are the natural media of cultural memory, frequently accompanied with basic methods of notation or prewriting such as the Australian tchurungas, the knotted cords (quipus) of the Incas, and similar mnemonic devices. For most of the time, these oral mnemotechniques were considered much more efficient than the early forms of writing. This is for many reasons. First, the contents of the cultural memory such as the great myths about the origin of the world, the tribe and its central institutions, the moral norms, and similar cultural texts are, so to speak, "mnemophilic"; they stick in the memory because of their poetic form and substantial relevance. We must not forget that writing was invented to record the non-mnemophilic, the contingent data in economy and administration, which no human memory can keep for a long period of time. Secondly, the various cultural texts (I am using this term like Clifford Geertz, who described the Balinese cockfight as a cultural text) tend to be multimedia productions, involving (besides language) pantomime, music, dance, ritual and may not easily be reduced to that one stratum of symbolic articulation that lends itself to transcription into writing. For this reason, it took the Mesopotamians and Egyptians more than a millennium to take this step. When writing is introduced into this domain, however, there is a high degree of probability that it will lead to drastic transformations.

When writing enters the realm of cultural memory, there seem to be three options: either to transcribe the oral texts and transform them into literature, or to compose entirely new texts whose complexity already requires writing for conceptualization and composition, or, finally, a combination of both. Mesopotamia and Israel seem to belong to the third category, Greece to the first, and Egypt to the second. The Homeric epics present 
themselves as transcripts of an oral performance, they exhibit their oral character. The same holds for Greek lyrical poetry, drama, and even the Platonic dialogues. This is not to exclude the possibility that Homer used writing for the composition of his epics. I am only stressing the fact that they imitate the form of oral composition and presentation. In Egypt, the situation is different. The earliest literary texts such as the "instructions" of Ptahhotep, Amenemhet I, and (for) Merikare, the complaints of Ipuwer and Khakheperreseneb, the prophecies of Neferti, the tales of the Shipwrecked Sailor, Sinuhe, and the Eloquent Peasant exhibit their genuinely literary character in the richness of vocabulary and grammar and their structural complexity. In Egypt, the use of writing for the work on cultural memory does not lead to the transcription or textualization of oral texts but to the composition of new genuinely written texts, in much the same way as in Western music culture, where the introduction of writing led to the composition of a new kind of music, polyphony. It was only 500 years later, with the New Kingdom and especially in the Ramesside age (1300-1100 вСE), that the use of writing extended to typically oral genres such as folk tales, love songs, harpers' songs, and so on that, however, disappeared again from the space of writing after 1100 BCE.

With the literarization of significant parts of cultural memory and the production of cultural texts that are conceptually literate (requiring writing already for composition and addressing a reader), a writing culture changes from sectorial to cultural literacy. Only at this point the techniques of writing and reading affect the connective structure of a society. One of the typical effects of this transformation is the construction of a glorious, heroic, or classical past or "antiquity." The cultural memory becomes two-storied, divided into the new and the old, modernity and antiquity. An important factor in this development is linguistic change. The older texts within the literary tradition, which now become validated as "classics," preserve a linguistic stage that no longer corresponds to the spoken language of the present. At a certain time, this distance between the "classical" and the vernacular idiom grows so wide that the classical language has to be learned specifically; we are dealing with cultural diglossia. This situation is typical of Mesopotamia as early as the third millennium, where Sumerians and Akkadians lived together speaking two completely different languages, and where Sumerian stayed in use for liturgic purposes until the age of Hellenism. With respect 
to the restricted use of Sumerian in this culture, we may speak of sectorial diglossia, which is a very widespread phenomenon. Cultural diglossia, on the other hand, is reached where and when the other language characterizes the cultural texts, those texts that carry the normative and formative knowledge, which constitutes and transmits a cultural identity across the sequence of generations and forms the diachronic backbone or connective structure of a society. This stage of cultural evolution characterizes the Cassite age in Mesopotamia (1550-1150 вСE) and the Ramesside age in Egypt (1300-1100 вСE).

The construction of a classical, heroic, or "golden" age, an "antiquity" as a past to look back at for models of behavior and literary production, means a first step in the direction of canonization. This cultural split into antiquity and modernity seems to me one of the characteristic prerequisites if not elements of axiality. It introduces into a given culture an element of critical distance and reflexivity. Canonization, at this first stage, means the collection of cultural texts of the past to form an obligatory syllabus of cultural knowledge, to be learned by heart and to be referred to as authoritative in critical discussions and situations. An Egyptian wisdom text of the thirteenth century вСE gives a list of eight "classics" of the past, whose models the pupil should follow in his strive for immortality. These authors achieved immortality, not by building pyramids but by writing books that are still read, learned, and quoted because of their ever valid truth and authority:

Is there anyone among us like Hordjedef?

Or someone like Imhotep?

Among our contemporaries, there is none like Neferti or Kheti, the greatest of them all.

I mention to you only the names of Ptahemdjehuti and Khakheperreseneb.

Is there another Ptahhotep or somebody like Kairsu? ${ }^{47}$

A German-Egyptian team discovered some years ago a tomb chapel in Assiut in the northern part of Upper Egypt that was reused during the New Kingdom for what seems to be a chapel of cultural memory. Some learned scribes had covered free spaces on the walls with large sections from classical texts of the Egyptian literary tradition containing two versions of the 
instruction of King Amenemhet I, the Instruction of Dua-Kheti, and the Hymn to the Nile, all three believed to be works of Kheti, "the greatest of them all," as well as two versions of the Loyalist Instruction by Kairsu, the Teaching of a Man for his Son, and the Prophecies of Neferti, ${ }^{48}$ thus six works of the classical tradition whose superior rank and high esteem as cultural texts is also documented by dozens or even hundreds of ostraca, limestone flakes that were used in school. The Egyptian scribe learned the craft by learning by heart the classical texts and by writing them down in appropriate portions using potsherds and limestone flakes as material. Another collection of Egyptian classics of the past can be found on a wall in a tomb at Saqqara dating from the thirteenth century все. ${ }^{49}$ The two lower registers, the only ones to have survived, list thirteen names apiece, the upper containing names of viziers and high priests of Ptah, the lower those of priests of slightly inferior rank, while the two sections are divided by a horizontal line that contains other names. Of these, four names reappear from the $\mathrm{Pa}$ pyrus Chester Beatty: Kairsu, Imhotep, Khakheperreseneb, and Kheti. The fifth is Ipuwer, the "author" of the Admonitions of Ipuwer, whose appearance confirms that lamentations and chaos descriptions (the genre to which belong also the works by Neferti and Khakheperreseneb) were also considered cultural texts of highest rank. Apart from these "authors," the list spans notables from the Old to the New Kingdom. The only name among these classics that is still unknown to us is Ptahemdjehuti. Hordjedef, Neferti, Kheti, Khakheperreseneb, Ptahhotep, Kairsu, and Ipuwer are known by their texts; Imhotep is known by a wealth of data, and his lost instruction is often referred to.

I think that the Egyptian case may be generalized. At a certain stage, every literate culture enters the stage of a split culture, divided into the old and the new, and it is writing in the form of cultural literacy that brings this split about. Since this split is dependent on linguistic change and finds its typical expression in the distinction between classical and vernacular language, and since linguistic change is a largely unconscious and uncontrolled process, we may even speak of evolution. The cultural and social consequences of this split, however, depend on cultural decisions and institutions.

Even the typically Egyptian association of this split with the idea of immortality may, at least to a certain degree, be generalized. In its literate, written form, cultural memory appears as a timeless or at least imperishable 
space of immortality, which one may enter by creating a book or work of art of everlasting beauty, truth, or significance. This idea of literary or artistic immortality may be considered as a first step in the direction of transcendence or transcendental visions (Eisenstadt). The use of writing for the fulfillment of the desire to transcend one's life span and to live on in the memory of posterity dates back, in Egypt, to the very beginnings of literate culture, but I would classify this use of writing for tomb inscriptions as sectorial literacy. The step toward cultural literacy is achieved when the tomb monument is topped by the literary work, for example in the words of Horace, who said with regard to his book of odes: "exegi monumentum aere perennius / regalique situ pyramidum altius." This motif appears already in the same Egyptian text that contains the canon of classical authors:

They [the sages of the past] have not created for themselves pyramids of ore nor stelae of iron; they have not contrived to leave heirs in the form of children, to keep their names alive.

But they created themselves books as heirs and teachings that they have written.

They employed the scroll as lector priest and the slate as "loving son."

Teachings are their pyramids, the reed their son, the polished stone surface their wife.

Their tomb chapels are forgotten,

but their names are recalled on their writings, that they have created,

as they endure by virtue of their perfection.

Their creators are remembered in eternity. ${ }^{50}$

We are not yet dealing here with "real" axiality, because this step of canonization is still culture-specific and lacks the global claims typical of Axial movements. But it is a step in the direction of axiality, and it is a step within the space of writing. 
Another sphere of cultural memory that is strongly affected by the use of writing is history. The existence of written sources about the past makes it possible to draw the distinction not only between the old and the new, but also between myth and history. The use of written records creates history in the sense of a critical discourse, separating mythical tales about the past from reasoned accounts of documented history. This step seems to be a Greek achievement, but the Greeks themselves attributed it to the Egyptians, opposing their own mythical form of historical consciousness to Egyptian history, which is based on written records. Typical examples of this intercultural comparison are Herodotus' account of the visit of Hecataeus of Miletus with the priests of Amun at Thebes ${ }^{51}$ and Plato's account of Solon's visit with the priests at Sais. ${ }^{52}$ Both Hecataeus and Solon confront the Egyptian priests with Greek traditions about the past. Hecataeus recites his own genealogy, which leads after fifteen generations to a god as the ancestor of the family, and Solon tells the Greek version of the story of the flood, the myth about Deukalion and Pyrrha. Both are then confronted by the Egyptians with their records. Hecataeus is led into the temple where he is shown 341 statues of high priests, one the son of the other and no god interfering, documenting 11,340 years of purely human history. Solon is shown the Egyptian annals stretching back over more than 9,000 years, where the memory of Athens' glorious past is preserved, for example their victory over Atlantis, which in Greece itself is destroyed and forgotten. All this is, of course, pure fabulation, but it illustrates the principle of critical history with its distinction between myth and history, brought about by the use of writing for chronological bookkeeping, which, in the form of annals and kinglists, belonged to the first and most important applications of writing in Egypt and Mesopotamia. In this sense of documented past and critical verifiability, it is writing that produced history and dispelled mythology. Writing caused history to be where myth was, because it documented conditions in which not gods but human kings reigned and in which humans were responsible for their actions. Writing bestows to historical memory the quality of verifiability and adds a truth value to its accounts about the past that myth, in spite of its truth claims, is lacking.

A third domain of cultural memory where the use of writing leads to dramatic changes is religion. It is here that the second and decisive step toward 
canonization is achieved, a step of truly global significance, which in my opinion forms the very center of Jaspers' concept of the Axial Age. In the realm of religion, writing appears with the same critical pathos as in the sphere of history, opposing its superior truth to the invalidated truth claims of myth. Here, its claims to superior truth are based on revelation, which it codifies. All world religions-Judaism, Christianity, Islam, Buddhism, Jainism, the religion of the Sikh, Confucianism, Daoism-are founded on a canon of sacred scripture that codifies the will of their founder and the superior truth of his revelation. This step of canonization was invented only twice in the world: with the Hebrew canon and the Buddhist canon. All later canons followed these examples. This second step of canonization changed the world in a truly "Axial" way.

The first step of canonization, which we encountered in Egypt and Mesopotamia, was connected with a cultural split into antiquity and modernity, drawing a distinction within the culture. Canonization here means the selection of the timelessly authoritative and exemplary texts from the plethora of written literature. The second canonization applies a different criterion: the criterion of absolute and universal truth, drawing a distinction that sets one's own culture or religion off against all other religions (including one's own past), which become now excluded as paganism, idolatry, heresy, and error. Some of this pathos of distinction and exclusion seems to me still present in Jaspers' concept of the Axial Age, which in this respect appears as a secularized version of the religious distinction between paganism and true religion. His idea of Axial civilizations puts the pre- and extra-Axial world in a position similar to the Jewish, Christian, and Islamic construction of paganism. This aspect becomes even stronger with Schwartz's definition of the Axial Age as the "age of transcendence" and Eisenstadt's concept of "transcendental visions" as the hallmark of axiality. All this is to a large degree a feat of cultural memory and an effect of writing and canonization. We don't know anything about the transcendental visions of shamans, kings, priests, and seers unless they become not only written down but, above all, are received into a canon of sacred scripture. It is only then that they become part of cultural memory and religious identity.

If primary canonization may be partly explained in terms of evolution dependent, as we have seen, on the truly evolutionary process of linguistic change, secondary canonization is by no means an evolutionary achieve- 
ment but a matter of conscious revolution, which in individual life could be compared to a conversion. The distinction between evolutionary processes and other forms of change implying conscious interventions and decisions between alternative options seems to me highly important in the study of the Axial Age.

In the West, the Hebrew canon of sacred scripture is complemented by a Greek and Latin canon of classical literature. The cultural memory of the West rests on these two projects of canonization, which were conducted roughly simultaneously-and probably not independently-by specialists in Palestine and Alexandria. The distinctive hallmark of what I call secondary canonization is the rise of exegesis. In the stage of primary canonization, the texts selected as classics exist in a form that the medievalist Paul Zumthor called mouvance. ${ }^{53}$ The texts were constantly reformulated, amplified, or substituted by other texts in order to accommodate them to the changing conditions of understanding. Their "surface structure" was sacrificed in order to save at least part of their meaning. This is why even written texts tend to exist over a longer stretch of time in many different versions. The continuous growth of the book of Isaiah, first into Deutero- then into Trito-Isaiah, is a typical case of how a cultural text is changing in what the Assyriologist Leo Oppenheim called "the stream of tradition." ${ }^{54}$ The Epic of Gilgamesh developed in the course of its transmission and redaction from a cycle of sagas into the "twelve-tablets-composition" in which it appears in the Neo-Assyrian library of Assurbanipal at Niniveh. In a similar way, the Egyptian Book of the Dead developed from a pool of unconnected spells out of which every individual funerary papyrus picked its own specific selection into a real book with a fixed selection of 167 spells in a fixed order. Written texts, in this "stream of tradition," share to a certain degree the sort of oral texts that are not fixed but subject to much variation over the course of time.

This flexibility or mouvance is categorically stopped and excluded by the process of secondary canonization. ${ }^{55}$ Secondary canonization means the combination of a sacralization of surface structure typical of sacred texts like hymns, incantations, and ritual spells on the one hand, and the preservation of meaning typical of cultural texts in the state of mouvance as the constant adaptation of the text to changing conditions of understanding on the other. Sacred texts are not necessarily cultural texts, since they may be known only to specialists and withheld from public circulation. Sacred texts 
are verbal enshrinements of the holy. In sacred texts, not a syllable must be changed in order to ensure the "magical" power of the words to "presentify" the divine. In this context, not "understanding" matters but correctness of pronunciation, ritual purity of the speaker, and other requirements concerning proper circumstances of performance. As the case of the Rgveda shows, this principle of non-mouvance and verbatim fixation applies to sacred texts independently of their oral or literate form of transmission. ${ }^{56} \mathrm{Sa}$ cred texts, therefore, are exempt from the pressure to adapt to the hermeneutical conditions of a changing world.

In the process of secondary canonization, the principle of sacred fixation is applied to cultural texts. On the one hand, they are treated like verbal temples enshrining divine presence, but on the other they require understanding and application in order to exert their formative and normative impulses and demands. The solution to this problem is exegesis. Exegesis or hermeneutics is the successor of mouvance. In the mouvance stage of literate transmission, the commentary is being worked into the fabric of the text. This method has been shown by Michael Fishbane to be typical of the biblical texts in their formative phase. ${ }^{57}$ They are full of glosses, pieces of commentary that later redactors have added to the received text. Only with the closure of the canon is this process stopped, and exegesis has now to take the form of a commentary that stays outside the text itself. ${ }^{58}$

This distinction between text and commentary typical of secondary canonization applies not only to the sacred but also to the classical canon. In this respect, the Alexandrinian philologoi seem to have led the way. They introduced into their collection of ancient writings the distinction between hoi prattómenoi (literally "those to be treated", that is, the classical texts worthy of exegetical treatment, of a commentary) and the rest. ${ }^{59}$ The Latin author Aulus Gellius compared this textual elite to the highest class of Roman taxpayers called "classici." In the Jewish tradition, this split into and relationship between text and commentary typical of secondary canonization finds its earliest expression in the concept of written and oral Torah (torah she be'al khitav and torah she be'al pe). Here, commentary has to be oral in order not to violate the space of writing, which is exclusively reserved for and occupied by sacred scripture. The oral Torah is a collection of oral debates and commentaries on the written Torah that became itself codified 
in the Talmudic and Midrashic traditions. It is believed to go back via an unbroken chain of reception (shalshelet ha-qabbalah) to Moses himself.

The oral exegesis of a sacred text accompanying its public recitation seems indeed to correspond to Jewish custom dating back to the beginnings of canonization. The book of Nehemiah reports a public reading of the Torah, where Ezra read the text and several of the Levites gave a commentary:

And Ezra opened the book in the sight of all the people, for he was above all the people, and as he opened it all the people stood. And Ezra blessed the LORD, the great God, and all the people answered, "Amen, Amen," lifting up their hands. And they bowed their heads and worshiped the LORD with their faces to the ground.

Also Jeshua, Bani, Sherebiah, Jamin, Akkub, Shabbethai, Hodiah, Maaseiah, Kelita, Azariah, Jozabad, Hanan, Pelaiah, the Levites, helped the people to understand the Law, while the people remained in their places. They read from the book, from the Law of God, clearly, and they gave the sense, so that the people understood the reading. (Neh. 8:5-8)

Some centuries later, the Jewish historian Flavius Josephus testifies to the same custom, where he confronts Jewish and Greek religion:

Can any government be more holy than this? or any Religion better adapted to the nature of the Deity? Where, in any place but in this, are the whole People, by the special diligence of the Priests, to whom the care of public instruction is committed, accurately taught the principles of true piety? So that the body-politic seems, as it were, one great Assembly, constantly kept together, for the celebration of some sacred Mysteries. For those things which the Gentiles keep up for a few days only, that is, during those solemnities they call Mysteries and Initiations, we, with vast delight, and a plenitude of knowledge, which admits of no error, fully enjoy, and perpetually contemplate through the whole course of our lives. ${ }^{60}$

It is obvious that Josephus, in this polemical passage, does not do full justice to the Greek organization of cultural memory. He ignores the classical 
canon, the traditions of scientific discourse, and the various forms of exegesis practiced in the schools of philosophy, medicine, and other branches of knowledge. He focuses only on religion and confronts the Jewish institutions of religious instruction and the Greek mystery cults. Arbitrary and highly selective as this comparison may be, it illustrates a very important distinction: the distinction between ritual and textual continuity. ${ }^{61}$

In spite of their extensive use of writing, Egyptian and other "pagan" religions were still relying on ritual continuity. In the world of ritual continuity, the public has indeed to wait for the next performance in order to get access to the sacred texts of cultural memory. Textual continuity is only achieved when institutions of learning and exegesis are established that keep the ancient texts constantly present and semantically transparent. The transition from ritual to textual continuity means a complete reorganization of cultural memory in the same way that the transition from the ethnically and culturally determined religions of the ancient world to the new type of transcultural and transnational world religions meant a totally new construction of identity. The canon, in a way, functioned as a new transethnical homeland and as a new transcultural instrument of formation and education.

There seems to exist a strong alliance among revelation, transcendence, and secondary canonization. The codification of revelation leads to a expatriation of the holy from the worldly immanence into transcendence and into scripture. The pagan or pre-Axial cult religions presuppose the immanence of the holy in images, trees, mountains, springs, rivers, heavenly bodies, animals, human beings, and stones. All this is denounced as idolatry by the new scripture-based world religions. Scripture requires a total reorientation of religious attention that was formerly directed toward the forms of divine immanence and is now directed toward scripture and its exegesis. Secondary canonization means an exodus both of the holy and of religious attention from the cosmos into scripture. To the extramundane nature of God corresponds the textual character of his revelation. To be sure, these remarks concern only the sacred canon such as the Tanakh, the Christian Bible, and the Qur'an, and not the canon of Greek and Latin classics. The structure of the classical canon is different in that it is open and allows for constant modifications around an unquestionable core, whereas the sacred canon is closed. This distinction between closed and open canons applies, however, only to the West. Eastern, especially Buddhist, canons 
have a different, less strict structure. Common to all corpora of secondary canonization is the existence of a full-fledged culture of exegesis and the strict distinction between text and commentary.

Seen as an agent of change, we may ask to which aspect of axiality literacy at the stage of secondary canonization makes the most decisive contribution. In my opinion, this is precisely the aspect of axiality that has been shown to function as a common denominator of most of the Axial features discussed above: distanciation and disembedding. Writing is a technology that restructures not only thought but also, under certain cultural circumstances, the whole network of relations between human beings, man and society, man and cosmos, man and god, and god and cosmos. The meaning of distanciation and disembedment as "Axial" moves, however, can only be properly understood if we get a better understanding of what embedment and integration mean.

In the evolutionary framework of the Axial narrative, embeddedness appears as the "not-yet" of the Axial achievement of distanciation and disembedding. What disappears in this perspective is the positive aspect of embedding. Embedding man in a social, political, and conceptual or ideological network of meaning and coherence and embedding the divine in a cosmic network whose meaning and coherence is modeled on the same basic ideas of order, truth, and harmony, should be recognized in its own right as a major civilizational achievement. There is perhaps no society on earth that went so far as the ancient Egyptians in articulating, elaborating, and also institutionalizing their vision of sociocosmic coherence, which they called Ma'at. There is no reason not to call this conceptualization a "transcendental vision." We cannot point to a "great individual" to have first formulated it, since no institutionalization of this first "vision" has been preserved, but the Egyptians themselves would have pointed to Imhotep, the first of their celebrated sages, who worked as a vizier under King Djoser (2750 BCE) and was divinized for his great invention, the art of building in stone, and the erection of the first pyramid, the step pyramid at Saqqara. His often-mentioned "instruction" is lost to us, but the transcendental character of the idea of Ma'at is obvious. Ma'at is what Kant would have called a "regulative idea."

Ma'at, however, works in the opposite direction of distanciation and disembedment. It is the very principle of embedment, of creating connectivity in the social, temporal, and cosmic dimensions, establishing social bonds 
between humans and temporal connections between yesterday, today, and tomorrow ensuring memory, success, stability, and even immortality. Who lives in and by Ma'at, this is the great Egyptian promise, will not perish but pass through the test of the judgment after death to eternal life in the Elysian fields. ${ }^{62}$ However, even this concept implies an element of distanciation, which is self-distanciation, renunciation from an immediate fulfillment of one's drives and impulses. The ideals of self-control, discretion, modesty, altruism, beneficence, openness to the needs of others, pity, compassion, empathy are at the core of the Egyptian concept of virtue. Knowing how to listen well is deemed more important than knowing how to speak well. This form of self-distanciation is the prerequisite for self-integration. It may also be described as a way of standing back and looking beyond: standing back from one's own narrow sphere of interests and looking beyond at the whole or at least a larger horizon of community. It is certainly not a mere coincidence that the hero of Egyptian wisdom was both a vizier and an architect. Knowing how to build a pyramid and knowing how to build a state and a society require comparable qualities. Certainly, this is not the kind of state and society we would very probably like to live in, and "Egyptian man," able to perfectly integrate him/herself into this pyramidal sociopolitical edifice is not man as we know or want him today, at least after the breakdown of the socialist totalitarianism, but even this construction of reality was illumined by transcendental visions, otherwise it would not have persisted for three millennia and more. It was certainly not the "house of slavery" as it is debunked in the Bible. ${ }^{63}$ What the Egyptian example may teach us is that even the pre-Axial world is the result of positive achievements and that the Axial breakthrough is not just the result of discoveries of what was unknown before, but also the result of conscious acts of rejection, abolition, rebellion that cannot be accounted for in an evolutionary perspective.

By adopting Christianity, the Egyptians themselves were able to perform a change in the most radical way. From champions of integration they turned into champions of isolation. To the ancient Egyptian mind, nothing could perhaps appear more absurd than total self-disembedding, since social embeddedness was identified with life, virtue, and morality. Seth, the god of evil and brutal violence, is the typical solitary one, and everyone fleeing from social life would be associated with Seth and considered as evil. ${ }^{64}$ After converting to Christianity, however, the Egyptians became virtuosos 
of solitude and went to unprecedented extremes in their search for isolation and renunciation. The Egyptian saint Anthony became the patron of Christian hermits, the Egyptian monasteries with their rules as codified by $\mathrm{Pa}-$ chom and Schenute became the models for Christian monasticism. The Egyptians adopted the Christian idea of the Kingdom of God as a goal of integration and reembedment with the same passion and perfection as previously the kingdom of Pharaoh, who was believed to be a god on earth and the son of the highest god.

To the disembedding of man from society and the world corresponds the disembedding of God from cosmic immanence and a pantheon of co-deities. These two movements of disembedding, that is, monotheism and the birth of individualism, have always been seen in strong connection. The connection becomes only the more obvious if one realizes that it is toward God that the hermit and toward man that God turns. The hermit abandons human society in order to draw nearer to God, and God, one could say, renounces divine companionship in favor of the "covenant" he establishes with his chosen people. In the early stages of biblical monotheism, the texts lay great stress on God's "jealousy" and compare the covenant between God and his people, God and man, to the erotic, sexual, and matrimonial bonds between man (God) and wife or bride (Israel). God can by no means be alone; what he abhors most and what puts him into fits of fury and jealousy is to be abandoned by his people. Man, in turn, leaves society not out of misanthropy but for the love of God. Both forms of solitariness, God's and man's, are not absolute but rest on a new form of partnership. In the frame of this partnership, man grows individualistic and God grows monotheistic.

It is fascinating to see how important a role writing, literacy, and scripture play even in this connection. With monotheism, the case is obvious. No monotheistic religion, in fact no "secondary" (i.e., founded) religion can do without a canon of sacred scripture. The solitude of God is, one could say, scripture-based. Similar statements apply to the solitude of man. Generally speaking, there can be a solitary reader but no solitary listener. Writing and reading create the possibility of communication without interaction. To scripture, however, this concept of interaction-free communication applies in a much more poignant sense. Studying the Torah and learning it by heart is the first and foremost requirement of man in the frame of monotheistic religion. Scripture, that is, the Torah, is the only mediator between the two 
solitary partners, God and man. Ger anokhi ba-'aretz ("I am a stranger on earth") the psalmist says in Psalm 119:19, adding: al-taster mimméni mitswoteýkha ("do not conceal thy commandments from me"). We see that also man's solitude, his alienation on earth, is scripture-based. God's commandments, which are codified in the Torah, offer him a home that he is missing "on earth." This home is what Heine called "ein portatives Vaterland" and what Bellah calls "a portable religion."

\section{Conclusion}

As a result of these considerations concerning literacy as an agent of change in the structure and organization of cultural memory, I have to confess that I cannot bring myself to really believe in the "Axial Age" as a global turn in universal history occurring grosso modo in the middle of the first millennium всE. On the other hand, I find the concept of axiality (with pre- and post-axiality) a valuable and even indispensable analytic tool in the comparative study of cultures. In my view, the stress on the alleged and in several cases undeniable synchronicity of Axial moves has led to an unnecessary mystification of the historical evidence. 65 These "breakthroughs" occurred in different civilizations at different times and to different degrees under different conditions and with different consequences. The undue fascination with time and simultaneity is the congenital defect of the Axial Age theory, lending it the character of a myth rather than a theory. We should give up the idea of synchronicity and, along with it, the tendency to describe the transition from pre-Axial to Axial to post-Axial stages exclusively in terms of evolution. There is, in my view, no evolutionary logic that leads from pre-Axial to Axial societies. Axiality implies always a revolutionary break, a "vertical" intervention of the spirit into the "horizontal" line of natural and cultural evolution.

As far as the "great individuals" are concerned, their appearance in recorded history stretches over several millennia. Akhenaten, who has every right to be included in this number, lived as early as the fourteenth century $\mathrm{BCE}$, Moses, if he ever lived, must equally belong to the second millennium $\mathrm{BCE}$, to which also Zoroaster is now dated by most scholars, whereas there is no reason why Jesus and Mohammad, who came much later, should be ex- 
cluded. Had his writings been preserved or his visions been institutionalized, we should even include Imhotep, who lived in the twenty-eighth century вСE. The decisive event is not the terrestrial existence of the great individuals but the canonization of their writings. The real "Axial Age" is not the age of the great individuals such as Akhenaten, Zoroaster, Moses, Homer, Isaiah, Plato, Confucius, Buddha, and so on, who did not wait until $800 \mathrm{BCE}$ to appear and who did not disappear by $200 \mathrm{BCE}$, but the age of secondary canonization. Canonization, as we have seen, is not an individual but a social and collective process. Canonization is the achievement of a society that decides to invest these texts with the highest values, to hold them in the greatest authority, to make them the basis of its life, or to follow their model in artistic creation. There were presumably always great individuals with "transcendental visions." Decisive is the step to turn these visions into "cultural texts," to select these texts into a canon and to frame the transmission of this canon by institutions of exegesis ensuring its availability, readability, and authority over 3,000 years.

If we insist on a first period of axialization, we could point to the years about $200 \mathrm{BCE}$ to $200 \mathrm{CE}$ when the great canons were established: the Confucian, the Daoist, and the Buddhist canons in the East, and the Avesta, the Hebrew Bible and the canon of Greek "classics" in the West. This is not the time when Homo sapiens axialis, "the human being with whom we are still living," came into being, but when the texts were canonized that we are still reading. The Axial Age is nothing else but the formative phase of the textual continuity that is still prevailing in our Western and Eastern civilizations.

If we have to give up the concept of an Axial "age" in the sense of a concrete time period in universal history, this does not mean that we have to give up the adjective "Axial" as well. "Axial," it is true, has strong temporal connotations. The axis around which history is believed to revolve, dividing this history into before and after, is a point or period in time. What we have to give up is the universality of this axis and this history. Different civilizations have different turning points in their history. That these turning points coincide temporally may be due to contact or to structural analogies. By no means, however, should this coincidence be promoted to a major factor in the interpretation of the turning point in question. Having occurred around $500 \mathrm{BCE}$ is not per se a feature of axiality. Neither have we to look for the roots of 
modernity exclusively in this period. It is our cultural memory that reaches back to Homer and Isaiah, but not the emergence of our modern world.

With regard to the ancient world, we are dealing neither with a mutation nor with a "blind" evolution, but with cultural processes stretching over several millennia, implying various historical factors and agents, and implying even reversibility, backward movements of "de-axialization," as has been rightly stressed by Eisenstadt on various occasions. Instead of an Axial "age," we should speak of axiality and axialization in the sense we speak of globalism and globalization, as a tendency that appears under different conditions in different "ages" of human history. Civilizations with a title to qualify as "Axial" should show significant forms of emancipation from tradition and primary world-embeddedness, and a pronounced tendency to formulate ideas or norms with a claim to universal validity. They should be able to produce a canon of texts enshrining these ideas and norms as well as institutions of learning and exegesis that keep their normative and formative impact alive until today. A given civilization arrives at the stage of axiality if these conditions are fulfilled.

It would be highly desirable to distinguish, within or below the two general categories of distanciation and universality, a certain number of "Axial features" such as reflexivity, individuality, interiority ("inner man"), progress in abstraction and intellectuality, theory, critique of tradition, differentiation, transcendental concepts or visions, and so on, and to arrive at a consensus concerning their definition. It is not necessary that all of them be present in a given civilization at a given epoch. Axiality, in my view, should not be conceived of as a Platonic idea ${ }^{66}$ that finds its expression in more or less perfection in the course of history, but rather in terms of "family resemblance" in the sense of Ludwig Wittgenstein. Family resemblance connects a set of items and a set of properties in the way that all items share some properties with some (not all) other items. Time (occurrence around 500 всE \pm 300 ) has to be ruled out as a significant property. Literacy in the form of cultural, not sectorial, literacy and perhaps even secondary canonization, together with a culture of exegesis as its necessary complement, are probably to be recognized as indispensable prerequisites for most of the "Axial features."

Another question is how to deal with precursors such as ancient Egypt and ancient Mesopotamia. Generalizing from ancient Egypt, my impression 
is that we should allow for proto-axiality in the sense of intermediate stages between non-axiality and full axiality in the same way as we distinguish prewriting from both pure orality and literacy proper. Among the protoAxial features in ancient Egypt, I would include the idea of an individual judgment after death with its concepts of individuality and moral responsibility, a rather strong concept of "inner man" in connection both with the judgment of the dead and the rise of "personal piety," a radical rejection of tradition in the context of King Akhenaten and his religious revolution, and, in the aftermath of this revolution, the development of strong concepts of divine transcendence. With regard to Mesopotamia, we may point to considerable steps toward canonization and a rich tradition of commentaries, to the level of theorizing in the fields of astronomy and mathematics, the astounding depth of certain literary texts (especially the Epic of Gilgamesh) and the beginnings of historiography. It should also be possible to discern specific "Axial moments" within the history of these and other civilizations that were obviously not numerous or strong enough to bring about the famous "breakthrough" into something that lasts until this day and has therefore a title to count as a root of modernity. It would also be important to account for this failure. Were there no "transcendental visions" in Mesopotamia and Egypt or were there no means of institutionalizing them?

As historians, we have to be careful not to characterize a civilization exclusively by the absence of features that we classify as "Axial" because they belong to our understanding of modernity, and to reconstruct the way that led from past to present civilizations exclusively in terms of evolution. Antiquity is much more than the mere "not yet" of modernity. Much has doubtlessly been lost along this way and much has been rediscovered that in reemerging from oblivion changed our world no less than real inventions and innovations. This is, however, only the historian's point of view, which is by no means the only one possible with regard to the past. It is equally important to look at the past not only for its own sake but also for the sake of the present and the future in order to get a clearer idea of where we come from and "whither we are tending." The idea of the Axial Age is not so much about "man as we know him" and his/her first appearance in time, but about "man as we want him" and the utopian goal of a universal civilized community. 


\section{Notes}

1. For this interpretation, see my book Thomas Mann und Ägypten: Mythos und Monotheismus in den Josephsromanen (Munich, 2006), 15-36.

2. Aleida Assmann calls this "Zentralperspektive in der Geschichte"; see her "Jaspers' Achsenzeit, oder: Schwierigkeiten mit der Zentralperspektive in der Geschichte," in Dietrich Harth, ed., Karl Jaspers-Denken zwischen Wissenschaft, Politik und Philosophie (Stuttgart, 1988), 187-205.

3. Thomas Mann, "Die Einheit des Menschengeistes" [1932], in Gesammelte Werke (Frankfurt am Main, 1975), vol. 10, 751-755.

4. For details, see my book Thomas Mann und Ägypten.

5. Erik H. Erikson, "The Ontogeny of Ritualization in Man," Philosophical Transactions of the Royal Society 251 B (1966): 337-349.

6. See Aleida Assmann, "Zeichen-Sprache-Erinnerung: Voraussetzungen und Strategien kultureller Evolution," in Heinrich Schmidinger and Clemens Sedmak, eds., Der Mensch - ein animal symbolicum? Sprache - Dialog-Ritual (Darmstadt, 2007), 27-40, esp. 38-40.

7. Dieter Metzler, Kleine Schriften zur Geschichte und Religion des Altertums und deren Nachleben (Münster, 2004), 565ff. and 577ff.

8. See Johann Arnason's inversion of Benjamin Schwartz's characterization of the Axial Age ("standing back and locking beyond") as a way of "standing beyond and looking back" in this volume, p. 349.

9. Aleida Assmann, "The Religious Roots of Cultural Memory," Norsk Teologisk Tidsskrift 4 (2008): 270-292. She uses the term in a more general sense than it is used in sociological discourse.

10. The distinction between "primary" and "secondary" religion goes back to Theo Sundermeier, "Religion, Religionen," in K. Müller and Th. Sundermeier, eds., Lexikon missionstheologischer Grundbegriffe (Berlin, 1987), 411-423, and Was ist Religion? Religionswissenschaft im theologischen Kontext (Gütersloh, 1999). See also Andreas Wagner, ed., Primäre und sekundäre Religion als Kategorie der Religionsgeschichte des Alten Testaments (Berlin and New York, 2006). My concept of "primary religion" corresponds to Charles Taylor's concept of "early religion," encompassing Bellah's "primitive" and "archaic" religion, although I agree with Bellah that the distinction between these two forms of religion is important. However, since there is an unbroken continuity between "primitive" or tribal and "archaic" religion (related to states and institutions of priesthood), whereas there is always a revolutionary break between these two and "Axial" or "secondary" religions, the first two types of religion may be taken together. I disagree, however, with Bellah in the assumption that the transition from "archaic" to "Axial" religion might be described in the same terms of evolution as the transition from "primitive" to "archaic."

11. For these questions, see my book Of God and Gods: Egypt, Israel and the Rise of Monotheism (Madison, 2008). 
12. Jaspers, The Origin and Goal of History (New Haven, 1953), 2. See also Johann Arnason, "The Axial Age and Its Interpreters: Reopening a Debate," in Johann Arnason, Shmuel Eisenstadt, and Björn Wittrock, eds., Axial Civilizations and World History (Leiden, 2005), 31-32.

13. Jaspers, Origin, 2. Yehuda Elkana elaborated on the notion of second-order thinking in his contribution "The Emergence of Second-Order Thinking in Classical Greece" in Shmuel Eisenstadt, ed., The Origins and Diversity of Axial Age Civilizations (Albany, 1986), 40-64.

14. Benjamin I. Schwartz, "The Age of Transcendence," Daedalus 104, no. 2 (1975): 1-7, here 3. On the concepts of "transcendence" and "transcendental" and Schwartz's contribution, see esp. Johann Arnason's chapter in this volume.

15. See, for example, Charles Taylor, A Secular Age (Cambridge, 2007). See also Karl Heinz Bohrer, Der Abschied: Theorie der Trauer; Baudelaire, Goethe, Nietzsche, Benjamin (Frankfurt am Main, 1997). Bellah, in his 1964 essay on "Religious Evolution," takes into account this change between the "Axial" form of religion and modernity in distinguishing, after "primitive," "archaic," and "historic religions" (i.e., Axial religions), two more recent steps: "early modern religions" and "modern religion." See "Religious Evolution," American Sociological Review 29 (1964): 358-374.

16. Obviously, we have to distinguish between the "other-worldly" and the "extra-mundane." Other-worldliness allows for degrees, extramundaneity has to be defined as a categorical chasm without any intermediate stages.

17. See my introduction to the German translation of Eric Voegelin, Ordnung und Geschichte, vol 1: Die kosmologischen Reiche des Alten Orients-Mesopotamien und Ägypten (Munich, 2002), 17-23.

18. See Jaspers, Origin, 2.

19. Arnaldo Momigliano, Alien Wisdom: The Limits of Hellenization (Cambridge, 1975), 8. See Robert Bellah, "What Is Axial about the Axial Age?," European Journal of Sociology 46 (2005): 69-89, here 72-73, and Hans Joas's contribution in this volume.

20. See Joas's chapter in this volume, n. 14.

21. Aleida Assmann, "Canon and Archive," in Astrid Erll and Ansgar Nünning, eds., Cultural Memory Studies: An International and Interdisciplinary Handbook (Berlin and New York, 2008), 97-107.

22. See Peter Schäfer, Der Triumph der reinen Geistigkeit: Sigmund Freuds "Der Mann Moses und die monotheistische Religion" (Berlin, 2002), and my article "Der Fortschritt in der Geistigkeit. Freuds Konstruktion des Judentums," PSYCHE: Zeitschrift für Psychoanalyse und ihre Anwendungen 56 (2002): 154-171.

23. David Riesman, The Lonely Crowd: A Study of the Changing American Character (New Haven, 1950). Riesman describes the emergence of (American) modernity as the transition from inner- to other-directedness, with reference, of course, not to the Axial Age but to the Industrial Revolution. 
24. The Great Transformation - the Beginning of Our Religious Traditions (New York, 2006); German translation: Die Achsenzeit: Vom Ursprung der Weltreligionen (Berlin, 2006).

25. She takes the term from Philippians 2:7: "he emptied himself taking the form of a bond-servant" (ả $\lambda \lambda \dot{\alpha} \dot{\varepsilon} \alpha v \tau o ̀ v ~ \varepsilon ̇ \kappa \varepsilon ́ v \omega \sigma \varepsilon v \mu o \rho \varphi \eta ̀ v ~ \delta o v ́ \lambda o v ~ \lambda \alpha \beta \omega ́ v)$.

26. For the ancient Egyptian ethics of altruism as self-distanciation, see my book Ma'at: Gerechtigkeit und Unterblichkeit im Alten Ägypten (Munich, 1990).

27. Charles Taylor, "The Future of the Religious Past," in Hent de Vries, ed., Religion: Beyond a Concept (New York, 2008), 178-244, here 185-186.

28. See, for example, Jörn Rüsen, ed., Westliches Geschichtsdenken (Göttingen, 1999).

29. Jaspers, Origin, 1 and 4 respectively.

30. Eric Voegelin, Order and History, vol. 1: Israel and Revelation (Baton Rouge, 1956), passim.

31. Anthony Kemp, The Estrangement of the Past: A Study in the Origins of Modern Historical Consciousness (New York and Oxford, 1991).

32. Jaspers, Origin, 16-17. Jaspers' indebtedness to Alfred Weber's Kulturgeschichte als Kultursoziologie (Leiden, 1935) goes in fact much beyond what he himself acknowledges.

33. This distinction between globalism and universalism corresponds grosso modo to Garth Fowden's distinction between "political universalism, which is shorthand for 'political, military, and economic universalism' and cultural universalism, which stands for 'cultural and especially religious universalism,' religions being understood to be a constituent part of the wider concept of culture." See G. Fowden, Empire and Commonwealth: Consequences of Monotheism in Late Antiquity (Princeton, 1993), 6-7.

34. Peter Artzi, "Ideas and Practices of International Co-existence in the 3rd mill. BCE," Bar Ilan Studies in History 2 (1984): 25-39; Artzi, "The Birth of the Middle East," in Proceedings of the 5th World Congress of Jewish Studies (Jerusalem, 1969), 120-124.

35. Miriam Lichtheim, Ancient Egyptian Literature, vol. 1: The Old and Middle Kingdoms (Berkeley, 1973), 224.

36. See Aleida Assmann, Zeit und Tradition: Kulturelle Strategien der Dauer (Cologne and Vienna, 1999); Klaus Koch, Europa, Rom und der Kaiser vor dem Hintergrund von zwei Jahrtausenden Rezeption des Buches Daniel (Hamburg, 1997); Mariano Delgado, Klaus Koch, and Edgar Marsch, eds., Europa, Tausendjähriges Reich und Neue Welt: Zwei Jahrtausende Geschichte und Utopie in der Rezeption des Danielbuches (Fribourg and Stuttgart, 2003).

37. The relationship between historical breakdown and spiritual breakthrough has already been proposed by Eric Weil in his contribution to the 1975 Daedalus volume: "What Is a Breakthrough in History?," 21-36. 
38. "Axial 'Breakthroughs' and Semantic 'Relocations' in Ancient Egypt and Israel," in Johann Arnason et al., Axial Civilizations, 133-156.

39. Walter J. Ong, "Writing Is a Technology That Restructures Thought," in Gerd Baumann, ed., The Written Word: Literacy in Transition (Oxford, 1986), 23-50.

40. "Mich dünkt, die Veränderung, die in den verschiedenen Zeiten der Kultur mit den Schriftzeichen vorgegangen, habe von jeher an den Revolutionen der menschlichen Erkenntnis überhaupt und insbesondere an den mannigfachen Abänderungen ihrer Meinungen und Begriffe in Religionssachen sehr wichtigen Anteil." Moses Mendelssohn, Jerusalem oder Über religiöse Macht und Judentum, in Schriften über Religion und Aufklärung, ed. Martina Thom (Berlin, 1989), 422-423.

41. See Aleida and Jan Assmann, "Einleitung: Schrift-Kognition-Evolution. Eric A. Havelock und die Technologie kultureller Kommunikation," in Eric A. Havelock, Die Schriftrevolution im antiken Griechenland (Weinheim, 1990), 1-36. On pp. 27-28 we give a bibliography of the works published by Ong, Goody, and Havelock until 1990.

42. On the distinction between "canon" and "archive," see Aleida Assmann, "Memory, Individual and Collective," in Robert E. Goodin and Charles Tilly, eds., The Oxford Handbook of Contextual Political Analysis (Oxford, 2006), 210-224.

43. Merlin Donald, Origins of the Modern Mind: Three Stages in the Evolution of Culture and Cognition (Cambridge, 1991), 308-315.

44. Schreibtafel BM 5645 rto. 2-7, ed. A. H. Gardiner, The Admonitions of an Egyptian Sage (Leipzig, 1909), 97-101; M. Lichtheim, Ancient Egyptian Literature I (Berkeley, 1973), 146-147; B. G. Ockinga, "The Burden of Khackheperrec sonbu," JEA 69 (1983): 88-95.

45. The term corresponds more or less to what Eric Havelock in his A Preface to Plato (Cambridge, 1963) calls "craft literacy."

46. See my book Cultural Memory and Early Civilization: Writing, Remembrance, and Political Imagination (Cambridge, 2012); see also Aleida Assmann, Cultural Memory and Western Civilization: Functions, Media, Archives (Cambridge, 2011).

47. Pap. Chester Beatty IV rto. 2.5-3.11; M. Lichtheim, Ancient Egyptian Literature, vol. 2: The New Kingdom (Berkeley, 1976), 177.

48. Ursula Verhoeven, "Literarische Graffiti in Grab N13.1 in Assiut/Mittelägypten," in P. Kousoulis, ed., Tenth International Congress of Egyptologists: Abstract of Papers (Rhodes, 2008), 262.

49. D. Wildung, Imhotep und Amenhotep: Gottwerdung im alten Ägypten (Munich, 1977), 28-29.

50. Pap. Chester Beatty IV rto. 2.5-3.11; D. Wildung, Imhotep und Amenhotep, 25-27.

51. Herodotus, Historiae II, chap. 143.

52. Plato, Timaios, 22b. 
53. P. Zumthor, Introduction à la poesie orale (Paris, 1983), 245-261; see also Aleida Assmann, "Schriftliche Folklore: Zur Entstehung und Funktion eines Überlieferungstyps," in Aleida and Jan Assmann, C. Hardmeier, eds., Schrift und Gedächtnis: Beiträge zur Archäologie der literarischen Kommunikation (Munich, 1983), 175-193.

54. Leo Oppenheim, Ancient Mesopotamia: Portrait of a Dead Civilization (Chicago, 1968), 13.

55. See Aleida and Jan Assmann, eds., Kanon und Zensur (Munich, 1987).

56 . The case of India, where the sacred texts were not written down but memorized by specialists, the Brahmin, seems to contradict this reconstruction, because here, in the context of oral tradition, we also meet with secondary canonization and traditions of exegesis. Here, however, the techniques of memorization have been brought to a degree of perfection that human memory could very well fulfill one of the main functions of writing, which is stabilizing the text. The decision to withhold the sacred texts from writing seems to have been common to several Indo-European religions such as Zoroastrianism and the Celtic Druidism. It is usually explained as an attempt to avoid the mistakes of copyists, but the main motive seems to have been the fear of unwanted dissemination, which is also one of Plato's arguments against writing. Stabilizing the text can be achieved either by writing or by an elaborate mnemotechnique. The latter requires usually a very strict poetic formalization of the text.

57. Michael Fishbane, Biblical Interpretation in Ancient Israel (Oxford, 1986).

58. See Jan Assmann and Burghard Gladigow, eds., Text und Kommentar (Munich, 1995).

59. See Ernst A. Schmidt, "Historische Typologie der Orientierungsfunktionen von Kanon in der griechischen und römischen Literatur," in Aleida and Jan Assmann, eds., Kanon und Zensur, 246-258.

60. Flavius Josephus, Contra Apionem, cap. 22, in W. Warburton, The Divine Legation of Moses (London, 1738-1741), vol. 1, 192-193.

61. For this distinction, see my book Das kulturelle Gedächtnis, 87-103.

62. For these beliefs, see my book Death and Salvation in Ancient Egypt (Ithaca, 2005).

63. It is also very important not to mistake the "connectivism" of Ma'at for the collectivism of certain modern ideologies. Collectivism presupposes the existence of ideas of communities such as tribe, people, nation, state, and so on that claim predominance over the individual member. None of these ideas exist in the ancient Egyptian lexicon, unlike, for example, the Hebrew Bible with its emphasis on concepts of community, especially the idea of a "holy people" (goj qadosh, Exod. 19:6).

64. See my article "Literatur und Einsamkeit im alten Ägypten," in Aleida and Jan Assmann, eds., Einsamkeit (Munich, 2000), 97-112. 
65. See also Stefan Breuer, Der Staat. Entstehung, Typen, Organisationsstadien (Reinbek, 1998), 101, and "Kulturen der Achsenzeit. Leistungen und Grenzen eines geschichtsphilosophischen Konzepts,” Saeculum 45, no. 1 (1994): 1-33.

66. Jaspers' "Platonism" has been criticized also by Jürgen Habermas, Philosophisch-politische Profile, 3rd ed. (Frankfurt am Main, 1981), 92. 